Sentralisasi Volume 8 (1) Hal : 33-42 | 2019

Analisis Audit Operasional Atas Pemberian Kredit...

DOI: https://doi.org/10.33506/sl.v8i1.382

Hanadelansa

\title{
Analisis Audit Operasional Atas Pemberian Kredit Pemilikan Rumah Pada PT Bank Rakyat Indonesia (Persero) Tbk Kantor Cabang Panakukkang di Kota Makassar
}

\author{
Hanadelansa $^{1}$, Rais Dera Pua Rawi ${ }^{2}$ \\ ${ }^{1}$ Fakultas Ekonomi STIE Wira Bhakti Makassar \\ ${ }^{2}$ Fakultas Ekonomi Universitas Muhammadiyah Sorong \\ Email.Hanadelansa@gmail.com
}

direvisi: 23 Januari 2019 dipublikasikan: 31 Januari 2019

\begin{abstract}
Abstrak
Penelitian ini bertujuan untuk mengetahui pelaksanaan audit operasional atas prosedur pemberian kredit pemilikan rumah pada PT Bank Rakyat Indonesia (Persero) Tbk Kantor Cabang Panakukkang di Kota Makassar. Metode pengumpulan data yang digunakan dalam penelitian ini adalah Pengumpulan data dilakukan dengan menggunakan teknik kuesioner,wawancara, dokumentasi dan observasi. Analisis data dilakukan dengan teknik analisis deskriptif komperatif dan menggunakan rumus Champion. Sampel yang digunakan adalah karyawan bagian pemberian kredit pada PT Bank Rakyat Indonesia (Persero) Tbk Kantor Cabang Panakukkang di Kota Makassar sebanyak 10 orang. Dari hasil analisis data kuesioner atas variabel independen yang diajukan kepada 10 responden maka diperoleh jawaban Ya sebanyak 286 dan jawaban Tidak sebanyak 54. Berdasarkan analisis data maka diperoleh nilai Champion sebesar 84,12\%. Dimana berdasarkan teori dengan skor tingkat persentase 76-100\% dikualifikasikan High association up to perpect association yang artinya pelaksanaan audit operasional atas pemberian kredit pemilikan rumah yang dilaksanakan sesuai dengan kriteria tahapan audit operasional yang berlaku umum. Yang berarti bahwa hipotesis yang diajukan diduga bahwa pelaksanaan audit operasional atas pemberian kredit pemilikan rumah yang dilaksanakan belum sesuai dengan kriteria tahapan audit operasiona ditolak.
\end{abstract}

Kata Kunci: Audit Operasional, Kredit Kepemilikan Rumah, BRI

\begin{abstract}
Abstrak
This study aims to determine the implementation of operational audits on the procedure for granting home ownership loans to PT Bank Rakyat Indonesia (Persero) Tbk Panakukkang Branch Office in Makassar City. Data collection methods used in this study are data collection using questionnaire techniques, interviews, documentation and observation. Data analysis was performed with comparative descriptive analysis techniques and using Champion formula. The sample used was a loan division employee at PT Bank Rakyat Indonesia (Persero) Tbk with 10 people at the Panakukkang Branch Office in Makassar City. From the results of the analysis of questionnaire data on the independent variables submitted to 10 respondents, the answers obtained were as many as 286 and No answers as many as 54. Based on data analysis, the Champion value is $84.12 \%$. Where based on the theory with a percentage level score of $76-100 \%$ qualified High association up toect association, which means that the implementation of an operational audit of the provision of home ownership loans is carried out in accordance with the general operational criteria stages of the audit, Which means that the proposed hypothesis is suspected that the implementation of an operational audit on the provision of housing loans that have not been carried out in accordance with the operational audit stage criteria is rejected.
\end{abstract}

Keywords: Operational Audit, Home Ownership Credit, BRI 


\section{Sentralisasi Volume 8 (1) Hal : 33-42 | 2019}

Analisis Audit Operasional Atas Pemberian Kredit...

DOI: https://doi.org/10.33506/sl.v8i1.382

Hanadelansa

\section{Pendahuluan}

Bank mempunyai kedudukan sangat penting dalam membangun perekonomian di Indonesia karena fungsinya sebagai penyalur pinjaman dana kredit. Sebagian besar kredit modal sektor usaha yang berlangsung dibiayai oleh bank sehingga bank dikatakan sebagai pemasok sebagian besar uang yang beredar di pasaran dan dijadikan sebagai alat tukar atau alat pembayaran. Bank juga merupakan lembaga keuangan yang di dalam kegiatan usahanya mengendalikan kepercayaan masyarakat sehingga tingkat kesehatan bank perlu dipelihara. Maksud dari kesehatan suatu bank di sini, dapat diartikan sebagai kemampuan suatu bank untuk melakukan kegiatan operasional perbankan secara normal dan mampu memenuhi semua kewajibannya dengan baik yang sesuai dengan peraturan perbankan yang berlaku. Kegiatan audit dalam suatu badan usaha seperti bank merupakan tuntutan atau kebutuhan bagi semua pihak guna melahirkan usaha yang sehat. Kegiatan ini pada hakikatnya mendorong terciptanya efisiensi usaha sehingga bank mampu bersaing secara sehat dalam pasar yang makin kompetitif dan memicu penciptaan laba yang baik. Dalam hal ini tentunya bank diharapkan terjaga kelangsungan hidupnya serta mampu memberikan kontribusi bagi negara dan masyarakat banyak.

Sebagai lembaga keuangan salah satu kegiatan perbankan adalah memberikan fasilitas kredit kepada masyarakat yang membutuhkan, dengan harapan bahwa kredit tersebut dapat menumbuhkan kegiatan usaha dan meningkatkan perekonomian dengan memberikan fasilitas kredit. Bank juga dapat membantu para pengusaha dalam memperkuat permodalannya dan dapat memperluas kesempatan kerja guna meningkatkan taraf hidup masyarakat pada umumnya. Mengingat salah satu jasa perbankan adalah di bidang perkreditan maka bank berupaya memenuhi kebutuhan masyarakat di satu sisi dan meningkatkan pendapatan di sisi lain serta menunjukkan antara kredit dengan bank merupakan suatu kesatuan yang sulit dipisahkan. Semakin besar volume kredit yang disalurkan maka semakin besar pula pendapatan yang akan diperoleh.

Salah satu kredit yang paling banyak diminati masyarakat adalah kredit konsumtif dan bank milik negara secara luas telah menyediakan pendanaan bagi masyarakat untuk membiayai keperluan seperti untuk membeli rumah, renovasi rumah, modal-modal kerja, 


\section{Sentralisasi Volume 8 (1) Hal : 33-42 | 2019}

Analisis Audit Operasional Atas Pemberian Kredit... DOI: https://doi.org/10.33506/sl.v8i1.382

Hanadelansa

sekolah dan kebutuhan konsumtif lainnya. Seiring dengan perkembangan dunia perbankan yang terus mengalami peningkatan,menyebabkan timbulnya persaingan yang semakin ketat dalam dunia perbankan. Bersamaan dengan maraknya persaingan antar bank tersebut, kredit bermasalah dan kredit macet juga banyak melanda dunia perbankan.

Penilaian atau prosedur pemberian kredit dilakukan secara mendalam namun tetap mengalami kredit macet atau nasabah tidak mampu melunasi kreditnya. Hal ini disebabkan oleh dua faktor yaitu pihak debitur dan pihak perbankan. Tidak semua debitur mempunyai itikad baik pada saat mengajukan permohonan kredit dan itikad tidak baik inilah yang sulit dianalisis oleh pihak bank. Bisa saja debitur memberikan data keuangan palsu atau berbagai tindakan-tindakan lainnya. Sedangkan dari pihak perbankan, biasanya pengambil keputusan pemberian kredit tidak memperhatikan prosedur pemberian kredit yang berlaku seperti kurang teliti dalam mengecek kebenaran dan keaslian dokumen karena ingin mengejar target sehingga bank agresif untuk menyalurkan dananya tanpa mempertimbangkan faktor resiko yang dapat muncul sewaktu-waktu. untuk mengatasi kredit bermasalah yaitu dengan cara mengadakan kegiatan audit operasional.

Audit operasional sangat diperlukan untuk menindaklanjuti berbagai permasalahan yang mungkin terjadi dalam kegiatan bank khususnya dalam hal pemberian kredit, sehingga dapat diketahui seberapa besar keefesienan dan keefektifan pemberian kredit agar dapar bersaing dipasar bank. Adapun tujuan yang ingin dicapai dalam penelitian ini adalah untuk mengetahui pelaksanaan audit operasional atas prosedur pemberian kredit pemilikan rumah pada PT Bank Rakyat Indonesia (Persero) Tbk Kantor Cabang Panakukkang di Kota Makassar.

\section{Metode Penelitian}

Penelitian ini menggunakan jenis penelitian kualitatif. Penelitian kualitatif adalah penelitian yang bersifat informasi atau keterangan yang diperoleh melalui kuesioner, wawancara, observasi, kepustakaan dan dokumen PT Bank Rakyat Indonesia (Persero) Tbk Kantor Cabang Panakukkang di Kota Makassar. Populasi yang terkait dalam penelitian ini adalah karyawan pada PT Bank Rakyat Indonesia (Persero) Tbk Kantor Cabang Panakukkang di Kota Makassar sebanyak 35 orang dan sampel dalam penelitian 


\section{Sentralisasi Volume 8 (1) Hal : 33-42 | 2019}

Analisis Audit Operasional Atas Pemberian Kredit... DOI: https://doi.org/10.33506/sl.v8i1.382

Hanadelansa

ini adalah karyawan pada bagian pemberian kredit PT Bank Rakyat Indonesia (Persero) Tbk Kantor Cabang Panakukkang di Kota Makassar sebanyak 10 orang.

Teknik pengumpulan data, menggunakan teknik kuesioner, wawancara, dokumentasi dan observasi. Selanjutnya teknik analisis data yang digunakan adalah analisis deskriptif komparatif. Skala pengukuran variabel yang diambil adalah skala ordinal dengan model pertanyaan kepada responden berikut 2 (dua) pilihan jawaban yaitu dengan bentuk atau model jawaban "Ya" dan "Tidak". Analisis data dilakukan dengan menggunakan perhitungan persentase (\%) yang menunjukkan bagaimana pelaksanaan audit operasional atas prosedur pemberian kredit dilihat melalui tahapan audit operasional. Persamaan yang digunakan menurut Champion (2001) yaitu dengan menghitung jumlah jawaban "Ya", kemudian dilakukan perhitungan dengan cara sebagai berikut:

$$
\text { persentase }=\frac{\text { Jumlah jawaban "Ya" }}{\text { Jumlah seluruh jawaban responden }} \times 100 \%
$$

Selanjutnya setelah diperoleh hasil dari interprestasi dari persentase nilai akhir, maka ditarik kesimpulan sesuai yang dikemukakan oleh Champion (2001:301) yaitu : (1) 0\% $-25 \%=n o$ association or low association; (2) $26 \%-50 \%=$ moderately low association; (3) $51 \%-75 \%=$ moderately high association; (4) $76 \%-100 \%=$ high association up to prefect association.

\section{Hasil Dan Pembahasan}

PT Bank Rakyat Indonesia (Persero) Tbk Kantor Cabang Panakukkang di Kota Makassar merupakan salah satu bank milik negara yang secara luas telah menyediakan pendanaan bagi masyarakat untuk tujuan konsumtif. Diantara kredit konsumtif yang paling banyak diminati masyarakat adalah kredit pemilikan rumah. Kredit ini diberikan untuk membiayai keperluan pembelian rumah atau pembangunan dan renovasi rumah tinggal, rumah toko (ruko), rumah kantor (rukan) atau kebutuhan konsumtif lainnya. 


\section{Sentralisasi Volume 8 (1) Hal : 33-42 | 2019}

Analisis Audit Operasional Atas Pemberian Kredit...

DOI: https://doi.org/10.33506/sl.v8i1.382

Hanadelansa

Tabel 2 : Data Realisasi Kredit Pemilikan Rumah dan Penerimaan Piutang pada PT Bank Rakyat Indonesia Kantor Cabang Pankukkang di kota Makassar Tahun 2014 2017.

\begin{tabular}{ccccc}
\hline Tahun & $\begin{array}{c}\text { Realisasi } \\
\text { Kredit }\end{array}$ & $\begin{array}{c}\text { Penerimaan } \\
\text { Piutang (Rp) }\end{array}$ & NPL (Rp) & $\begin{array}{c}\text { Jumlah Debitur } \\
\text { (orang) }\end{array}$ \\
\hline $\mathbf{2 0 1 4}$ & 18.882 .932 .000 & 18.321 .563 .562 & 0,03 & 99 \\
\hline $\mathbf{2 0 1 5}$ & 74.831 .242 .000 & 71.140 .527 .336 & 0,05 & 413 \\
\hline $\mathbf{2 0 1 6}$ & 144.107 .854 .000 & 136.810 .156 .558 & 0,06 & 891 \\
\hline $\mathbf{2 0 1 7}$ & 335.524 .302 .600 & 325.003 .650 .000 & 0,03 & 167 \\
\hline
\end{tabular}

Sumber : Laporan tahunan PT Bank Rakyat Indonesia (Persero) Tbk Kantor Cabang Panakukkang di Kota Makassar

Berdasarkan tabel di atas dapat dilihat perkembangan realisasi kredit dan penerimaan piutang PT Bank Rakyat Indonesia (Persero) Tbk Kantor Cabang Panakukkang di Kota Makassar di tiap tahunnya. Dimana tahun 2014 hingga tahun 2017 jumlah kredit yang dicairkan semakin meningkat diiringi dengan penerimaan piutang dan jumlah nasabah. Di Tahun 2014 jumlah kredit yang dicairkan sebesar Rp 18.882.932.000,00 dan jumlah penerimaan piutang sebesar Rp 18.321.563.562,00 dengan jumlah debitur sebanyak 99 nasabah mengalami peningkatan di tahun 2015, dimana jumlah realisasi kredit menjadi Rp 74.831.242.000,00 dan jumlah piutang menjadi Rp 71.140.527.336,00 dengan jumlah debitur sebanyak 413 nasabah. Tahun 2016 realisasi kredit kembali mengalami peningkatan menjadi Rp 144.107.854.000,00 dan penerimaan piutang menjadi Rp 136.810.156.558,00 dengan jumlah debitur sebanyak 891 nasabah hingga tahun 2017 realisasi kredit terus mengalami peningkatan menjadi Rp 335.524.302.600,00 dan penerimaan piutang menjadi Rp 325.003.650.000,00 dengan jumlah debitur sebanyak 1673 nasabah. Peningkatan realisasi kredit, penerimaan piutang dan jumlah nasabah pada tidak lepas dari usaha pihak-pihak bank dalam melaksanakan tugasnya secara benar dan konsisten untuk mencapai keuntungan yang maksimal dengan resiko yang sekecil-kecilnya, sering mengadakan pameran dengan tingkat suku bunga yang rendah dan bersaing dengan bank lain serta memberikan pelayanan yang baik kepada nasabah.

Disamping peningkatan realisasi kredit dan penerimaan piutang, jumlah kredit macet juga mengalami peningkatan walaupun tidak terlalu signifikan. Dimana tahun 2014 jumlah kredit macet sebesar $0,03 \%$ meningkat menjadi $0,05 \%$ pada tahun 2015 . Tahun 2016 kredit macet kembali meningkat dari $0,05 \%$ menjadi $0,06 \%$. Naiknya jumlah kredit 


\section{Sentralisasi Volume 8 (1) Hal : 33-42 | 2019}

Analisis Audit Operasional Atas Pemberian Kredit... DOI: https://doi.org/10.33506/sl.v8i1.382

Hanadelansa

macet dapat terjadi karena prosedur pemberian kredit tidak dilaksanakan secara efektif dan efesien karena ingin mengejar target sehingga pemberian kredit yang dilakukan melampaui batas kemampuan pelunasan kredit oleh nasabah.

Di tahun 2017 jumlah kredit macet mengalami penurunan yang cukup signifikan dari $0,06 \%$ menjadi $0,03 \%$. Turunnya jumlah kredit macet dapat terjadi karena pihakpihak bank telah melaksanakan pengambilan keputusan secara seksama terhadap nasabah yang mengajukan kredit, pelaksanaan prosedur pemberian kredit juga telah dilaksanakan sesuai dengan persyaratan dan ukuran-ukuran penilaian yang ditetapkan sehingga pihak bank dapat meminimalisir terjadinya peningkatan kredit macet secara terus menerus. Kredit macet kerap kali menjadi permasalahan utama yang dihadapi dunia perbankan, demikian juga karena resiko yang diakibatkan kredit macet sangatlah besar. Seperti, terganggunya operasional bank, berkurangnya kepercayaan masyarakat terhadap bank itu sendiri atau bahkan bank tersebut gulung tikar. Selain itu, keadaan perekonomian yang tidak stabil yang menyebabkan harga beberapa kebutuhan masyarakat sehingga dapat berimbas pada keterlambatan untuk membayar cicilan kredit karena penghasilan tidak mencukupi lagi untuk memenuhi kebutuhan masyarakat yang serba naik.

Mengingat resiko yang diakibatkan kredit macet sangatlah besar maka bank perlu melakukan perbaikan-perbaikan sedini mungkin terhadap permasalahan yang terjadi seperti pelaksanaan prosedur pemberian kredit pemilikan rumah harus sesuai dengan teori perkreditan yang berlaku umum atau yang telah ditetapkan oleh bank, pemberian kredit yang sesuai dengan kemampuan pelunasan oleh nasabah serta meningkatkan pengawasa yang berkesinambungan setelah pemberian kredit sehingga pihak bank dapat mendeteksi dengan cepat permasalahan yang menjurus pada kredit macet.

Prosedur pemberian kredit pemilikan rumah pada PT Bank Rakyat Indonesia (Persero) Kantor Cabang Panakkukang di Kota Makassar telah sesuai dengan teori perkreditan yang telah dikemukan oleh Kasmir (2008:96) dimana dikatakan sebelumnya bahwa "prosedur pemberian kredit terdiri dari pengajuan proposal, penyelidikan berkas pinjaman, penilaian kelayakan kredit, wawancara pertama, wawancara kedua, peninjauan ke lokasi, keputusan kredit, penandatanganan akad kredit dan realisasi kredit”. Secara umum dapat dijelaskan bahwa sebelum calon debitur yang mengajukan kredit terlebih dahulu harus menjalani tahap demi tahap prosedur pemberian kredit pemilikan rumah dan 


\section{Sentralisasi Volume 8 (1) Hal : 33-42 | 2019}

Analisis Audit Operasional Atas Pemberian Kredit... DOI: https://doi.org/10.33506/sl.v8i1.382

Hanadelansa harus mematuhi ketentuan yang berlaku. Hal ini dilakukan untuk meminimalisasi kredit bermasalah yang terjadi akibat tidak dipatuhinya prosedur pemberian kredit atau ketentuan-ketentuan perkreditan bank yang bersangkutan. Dari hasil penyebaran kuesioner terhadap 10 responden dengan jumlah pertanyaan sebanyak 25 dapat diperoleh jawaban sebagai berikut :

Tabel 3 :Prosedur Pemberian Kredit Pemilikan Rumah

\begin{tabular}{lccc}
\hline \multicolumn{1}{c}{ Tahapan } & \multirow{2}{*}{ Item } & \multicolumn{2}{c}{ Jawaban } \\
Prosedur Pemberian Kredit & & Ya & Tidak \\
\hline Lingkungan pengendalian & 5 & 34 & 16 \\
\hline Penaksiran resiko & 6 & 44 & 16 \\
\hline Aktivitas pengendalian & 9 & 75 & 15 \\
\hline Pengumpulan Data Dan Informasi & 5 & 31 & 19 \\
\hline \multicolumn{1}{c}{ Jumlah } & $\mathbf{2 5}$ & $\mathbf{1 8 4}$ & $\mathbf{6 6}$ \\
\hline \multicolumn{1}{c}{ Persentase (\%) } & & $\mathbf{7 3 , 6 \%}$ & $\mathbf{2 6 , 4} \%$ \\
\hline
\end{tabular}

Sumber: Hasil Pengolahan Data

Meskipun demikian, hal-hal yang menjadi masalah pada prosedur pemberian kredit pemilikan rumah adalah belum ada tindakan manajemen dilakukan secara intensif untuk mengurangi tindakan pegawai yang berbuat jujur, dokumen persyaratan permohonan kredit pemilikan belum cukup menggambarkan kondisi calon debitur yang sebenarnya sehingga calon debitur dapat memberikan data keuangan palsu, manajemen juga belum melakukan perubahan lingkungan operasional dan sistem informasi pemberian kredit serta penggunaan prinsip-prinsip pemberian kredit atas kemungkinan salah saji laporan keuangan. Selain itu, aktivitas pemberian kredit pemilikan rumah juga belum aman dari penyimpangan dan penyalahgunaan dana oleh personel yang tidak bertanggung jawab.

Pelaksanaan audit operasional atas prosedur pemberian kredit pemilikan rumah PT Bank Rakyat Indonesia (Persero) Tbk Kantor Cabang Panakukkang di Kota Makassar dilakukan oleh tim (team work) auditor internal pada satuan pengawasan intern. Dalam suatu tim umumnya terdiri atas enam atau tujuh personalian yang terlibat, yaitu terdiri atas seorang pimpinan tim dan beberapa anggotanya yang langsung didatangkan dari kantor pusat Jakarta, dan ditempatkan di kantor inspeksi Makassar untuk memudahkan pengawasan intern. Yang mana masing-masing personil menangani elemen-elemen yang berbeda, sesuai dengan pembagian tugasnya, yakni ada yang menangani agunan atau 


\section{Sentralisasi Volume 8 (1) Hal : 33-42 | 2019}

Analisis Audit Operasional Atas Pemberian Kredit... DOI: https://doi.org/10.33506/sl.v8i1.382

Hanadelansa jaminan, administrasi maupun kelengkapan dokumen-dokumen yang diperlukan dalam kredit tersebut, logistik, SDM serta ada seseorang yang mengawasi dan mereview hasil dari pekerjaan internal auditor tersebut, yaitu pimpinan tim. Jumlah personil yang terlibat dalam satu tim dan jangka waktu dapat berubah sewaktu-waktu tergantung situasi yang dihadapi.

Berdasarkan pada hasil diatas, maka analisis uji hipotesis bahwa pelaksanaan audit operasional atas pemberian kredit pemilikan rumah pada PT Bank Rakyat Indonesia (Persero) Tbk Kantor Cabang Panakukkang di Kota Makassar belum sesuai dengan kriteria tahap-tahap audit operasional yang berlaku umum”. Untuk menguji diterima atau ditolaknya hipotesis tersebut, penulis ingin menyampaikan hasil jawaban kuesioner yang penulis terima dari 10 orang responden pada PT. Bank Rakyat Indonesia (Persero) Tbk Kantor Cabang Panakukkang di Kota Makassar. Dari hasil penyebaran kuesioner yang diajukan kepada 10 responden dengan jumlah pertanyaan sebanyak 34, diperoleh jawaban sebagai berikut:

Tabel 4 : Audit Operasional Yang Memadai

\begin{tabular}{|c|c|c|c|}
\hline \multirow{2}{*}{$\begin{array}{c}\text { Tahapan } \\
\text { Kualifikasi Auditor Internal }\end{array}$} & \multirow[b]{2}{*}{ Item } & \multicolumn{2}{|c|}{ Jawaban } \\
\hline & & Ya & Tidak \\
\hline Independensi & 3 & 23 & 7 \\
\hline Kompetensi & 4 & 32 & 8 \\
\hline \multicolumn{4}{|l|}{ Pelaksanaan Audit Operasional } \\
\hline Program audit & 4 & 33 & 7 \\
\hline Pelaksanaan audit operasional & 7 & 65 & 5 \\
\hline Laporan hasil audit operasional & 6 & 55 & 5 \\
\hline Tindak lanjut atas laporan hasil audit operasional & 2 & 19 & 1 \\
\hline \multicolumn{4}{|c|}{$\begin{array}{c}\text { Tercapainya Fungsi Audit Opersional Atas Pemberian } \\
\text { Kredit }\end{array}$} \\
\hline Verifikasi & 2 & 13 & 7 \\
\hline Compliance & 2 & 13 & 7 \\
\hline Evaluasi & 2 & 15 & 5 \\
\hline $\begin{array}{l}\text { Pelaksanaan audit operasional atas prosedur pemb } \\
\text { kredit }\end{array}$ & 2 & 18 & 2 \\
\hline Jumlah & 34 & 286 & 54 \\
\hline
\end{tabular}

Sumber : Hasil Pengolahan Data

Berdasarkan tabel 4 dan kesimpulan diatas mengenai pelaksanaan audit operasional atas pemberian kredit pemilikan rumah maka hasil perhitungan diperoleh sebagai berikut : 


\section{Sentralisasi Volume 8 (1) Hal : 33-42 | 2019}

Analisis Audit Operasional Atas Pemberian Kredit...

DOI: https://doi.org/10.33506/sl.v8i1.382

Hanadelansa

$$
\text { Persentase }=\frac{286}{340} \times 100 \%=84,12 \%
$$

Dari hasil penelitian perhitungan kuesioner tersebut dengan hasil 84,12\% dapat disimpulkan bahwa pelaksanaan audit operasional atas pemberian kredit pemilikan rumah yang dilaksanakan sesuai dengan kriteria tahapan audit operasional yang berlaku umum.

\section{SIMPULAN}

Berdasarkan analisis yang dilakukan terhadap data-data yang meliputi struktur organisasi, kegiatan usaha, prosedur pemberian kredit pemilikan rumah serta pelaksanaan audit operasional atas pemberian kredit pemilikan rumah maka ditarik kesimpulan sebagai berikut : Dari hasil perhitungan kuesioner di peroleh hasil 84,12\% sehingga dapat disimpulkan bahwa Pelaksanaan audit operasional atas pemberian kredit pemilikan rumah yang dilaksanakan oleh auditor internal pada PT Bank Rakyat Indonesia (Persero) Tbk Kantor Cabang Panakukkang di Kota Makassar. Disisi lain, Pelaksanaan prosedur pemberian kredit pemilikan rumah telah sesuai dengan teori perkreditan yang ada. Hal ini dilakukan untuk meminimalisasi kredit bermasalah pada bank yang bersangkutan.

\section{Daftar Pustaka}

Champion, Dean, J. 2001. Basic Statistic For Social Research. McMilan publishing Co. Inc. New York. (http://repository.usu.ac.id, diakses tanggal 14 Mei 2011)

Hadi Kartika. 2000. Kumpulan Baca Manajemen Audit.Jakarta : PPA FEUI

Halim. 2003. Auditing (Dasar-Dasar Audit Laporan Keuangan). Yogyakarta: BPFE Yogyakarta

Hasibuan, SP, Melayu. 2006. Dasar-Dasar Perbankan.Jakarta : Bumi Aksara

Hermansyah.2006. Hukum Perbankan Nasional Indonesia.Jakarta : Kencana Prenada Media Group.

IBK. Bayangkara. 2008 Audit Manajemen: Prosedur dan Implementasi.Jakarta : Salemba Empat Indrianto Nur dan Supomo Bambang. 2002. Metodologi Penelitian Bisnis untuk Akuntansi dan Manajemen. Yogyakarta : BPFE. 


\section{Sentralisasi Volume 8 (1) Hal : 33-42 | 2019}

Analisis Audit Operasional Atas Pemberian Kredit... DOI: https://doi.org/10.33506/sl.v8i1.382

Hanadelansa

Kasmir. 2002. Manajemen Perbankan.Jakarta : PT. Raja Grafindo Persada.

Muljono Teguh Pudjo. 1990. Aplikasi Manajemen Audit Dalam Industri Perbankan. Yogyakarta : BPFE Yogyakarta.

P. Siagian, Sondang. 2001. Audit Manajemen. Jakarta : Bumi Aksara

Sugiyono. 2007. Statistika Untuk Penelitian. Bandung : Alfabeta

Sukidin, Basrowi. 2002. Metodologi Penelitian Kualitatif Perspektif Mikro. Surabaya : Insan Cendekia.

Sunarto, 2003.Aspek-Aspek Hukum Perkreditan pada Bank.Jakarta : Alfabeta.

Susilo, Y, Sri, dkk. 2000. Bank dan Lembaga Keuangan Lain.Jakarta : Salemba Empat.

Suyatno, dkk. 2005. Memahami Penelitian Kualitatif. Bandung : Alfabeta.

Tunggal , Amin Widjaja. 2001. Audit Operasional (Suatu Pengantar). Jakarta: Harvindo

Usman Husaini, dkk. 2004. Metodologi Penelitian Sosial. Jakarta : Bumi Aksara.

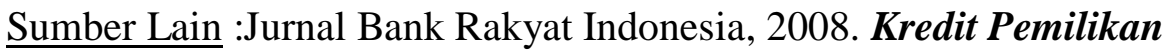

